Experimental study of torrefied pine as a gasification fuel using a bubbling fluidized

\title{
bed gasifier
}

\author{
Avanti Kulkarni ${ }^{\mathrm{a}}$, Ryan Baker ${ }^{\mathrm{a}}$, Nourredine Abdoulmomine ${ }^{\mathrm{b}}$, Sushil Adhikari ${ }^{\mathrm{a}}$ and Sushil $^{\mathrm{a}}$
}

Bhavnani $^{\mathrm{c}}$

${ }^{a}$ Department of Biosystems Engineering, Auburn University, Auburn, AL 36849

${ }^{b}$ Department of Biosystems Engineering and Soil Sciences, University of Tennessee, Knoxville, TN 37996

\section{${ }^{c}$ Department of Mechanical Engineering, Auburn University, Auburn, AL 36849}

\section{Abstract}

Torrefied biomass has higher $\mathrm{C} / \mathrm{O}$ ratio, resulting in improved heating value and reduced hygroscopic nature of the biomass, thus enabling longer storage times. In the southeastern United States, pine is has been identified as a potential feedstock for energy production. The objective of this study was to understand the performance of torrefied pine as a gasification fuel in a benchscale bubbling fluidized bed gasifier. The gasification of torrefied pine was carried out at 790, 935 and $1000^{\circ} \mathrm{C}$ and three equivalence ratios (ERs: 0.20, 0.25 and 0.30). The effect of process variables were studied based on i) products yield, ii) syngas composition iii) syngas energy content, and iv) contaminants. The mean concentration of $\mathrm{CO}$ increased with an increase in temperature, but was not statistically significant. On the other hand, $\mathrm{H}_{2}$ concentration increased whereas $\mathrm{CH}_{4}$ concentration decreased significantly with an increase in temperature from 790 to $935^{\circ} \mathrm{C}$. Further, with an increase in ER from 0.20 to 0.30 , only $\mathrm{CO}_{2}$ concentrations increased in the syngas. Results from torrefied pine were compared with raw pine gasification, and it was

\footnotetext{
"Corresponding author. Tel: +1 334844 3543; fax: +1 3348443530

Email address: sushil.adhikari@ auburn.edu (S. Adhikari)
} 
23 observed that torrefied pine gasification led to much higher char yield (more than twice) than

24 pine; however, it produced less than half as much tar.

25 Keywords: torrefaction; biomass; syngas; contaminants; tar

\section{1. Introduction}

27 The energy production from coal has drastically decreased with recent increase in natural gas

28 production [1]. Along with increase in natural gas production, the improved emission standards

29 have forced several coal power plants in the United States to use it. One alternative to its usage is

30 to explore coal-biomass co-feeding scenarios that can help meet the emissions standard. In the

31 southeastern U.S., the abundant forest resources provide the opportunity for co-feeding biomass

32 with coal to help meet the emission goals [2-4]. However, several issues such as low energy

33 density, high moisture content, low bulk density, higher transportation cost and low grindability

34 associated with the raw biomass impede coal-biomass co-feeding [5-7]. Therefore, biomass

35 pretreatment has been suggested to improve its properties and enable co-feeding in existing coal

36 plants $[8,9]$. Torrefaction is one such pretreatment method. During this process hemicellulose is

37 decomposed and increases grindability of biomass, improves energy and carbon content, and

38 bulk density while reducing the hygroscopic nature, and thus making biomass handling easier [8-

39 13]. One of the key benefits of this process is increase in biomass energy and carbon content

40 closer to that of coal. This makes torrefied biomass an excellent choice for co-feeding with coal

41 for power generation purposes.

42 A handful studies have been performed on understanding the characteristics of torrefied biomass

43 and its effect on syngas composition from gasification [14-19]. Some studies have conducted

44 bench-scale studies to understand effect of densification along with torrefaction [16], while 
45 others have performed simulations [15] to understand performance of torrefied biomass. Few

46 pilot scale studies have also been reported $[14,17]$. However, only a few of these studies have

47 reported the contaminants released along with the primary syngas composition [14]. Couple of

48 studies with torrefied biomass have been conducted using downdraft gasifiers $[14,16]$. The

49 torrefaction or pretreatment of biomass affects the syngas production and composition. Kuo et al.

50 [15] studied performance of torrefied bamboo using thermodynamic simulation and observed

51 that torrefied bamboo produced lower hydrogen concentration and higher CO production. While

52 Strandberg et al. [18] observed a reduction in methane production from torrefied saw dust when

53 compared with raw saw dust in a pilot-scale entrained flow gasifier. Gasification of torrefied

54 biomass in a downdraft gasifier $[14,17]$ produced syngas with comparable syngas composition

55 and energy content with raw biomass samples. However, Dudyński et al. [14] reported unstable

56 temperature inside gasifier during torrefied biomass gasification. Sarkar et al. [16] suggested that

57 when torrefaction was accompanied by densification, the syngas composition and carbon

58 conversion increased. A study on torrefied Miscanthus x giganteus by Xue et al. [19] on a TGA

59 suggested that torrefied biomass favored gasification at higher temperatures (above $850^{\circ} \mathrm{C}$ ).

60 It is clear based on the information available in the open literature that there is no study on

61 torrefied biomass in a fluidized bed gasifier. If a large scale application is desired then it is

62 important to understand the performance of torrefied biomass as a feedstock in a fluidized bed

63 gasifier. The availability of pine in the Southeast and growing interest in torrefaction as a

64 pretreatment process encouraged a comprehensive study of torrefied pine as a gasification fuel in

65 a bubbling fluidized bed gasifier. The objective of this study was to experimentally investigate

66 the performance of torrefied pine at three temperatures and equivalence ratios (ERs) based on the

67 syngas composition $\left(\mathrm{CO}, \mathrm{CO}_{2}, \mathrm{CH}_{4}, \mathrm{H}_{2}, \mathrm{C}_{2} \mathrm{H}_{2}, \mathrm{C}_{2} \mathrm{H}_{4}\right)$, syngas energy, cold gas efficiency and the 
68 contaminants $\left(\mathrm{HCl}, \mathrm{HF}, \mathrm{NH}_{3}, \mathrm{HCN}, \mathrm{SO}_{2} \mathrm{COS}\right.$ and tar) produced when gasified using a bench-

69 scale bubbling fluidized bed with sand as the bed material. A comparison was made between

70 torrefied and raw pine gasification to better understand the effect of torrefaction on the

71 performance of pine.

\section{2. Materials and Methodology}

\section{$73 \quad 2.1$ Materials}

74 Southern pine was used for this gasification. Torrefied pine was obtained in the pelletized form

75 whereas raw pine biomass (same biomass that was used for torrefaction) was received in chips

76 from New Biomass Energy, LLC (Quintman, Mississippi). The pellets were ground and sieved

77 through a $850 \mu \mathrm{m}$ sieve before feeding into the gasifier. In the case of raw pine chips, they were

78 first air-dried, ground, and also sieved through the same screen prior to gasification. The

79 elemental analysis of biomass was performed using CHNS/O analyzer (Perkin Elmer, model

80 2400, Waltham, MA) and the higher heating value was obtained using bomb calorimeter (IKA

81 Bomb Calorimeter, Model C-200, Wilmington, NC). The ash content, volatile matter and

82 moisture content were performed according to ASTM D1102, BS EN 15148:2009, and ASTM

83 E871, respectively. Structural carbohydrates and lignin were measured using an NREL (National

84 Renewable Energy Laboratory) Laboratory Analytical Procedure (LAP) entitled "Determination

85 of structural carbohydrates and lignin in biomass"[20].

\subsection{Experimental setup}

87 The experiments were carried out using a bench-scale bubbling fluidized bed gasification rig. A 88 detailed description of this set up has been presented elsewhere[21]. Briefly, the set-up consisted

89 of a hopper, an auger feeder, a fluidized bed gasifier, a high temperature filter unit (HTF), a pair 
90 of condensers, an electrostatic precipitator and a tar analysis impinger train. The bubbling

91 fluidized bed gasifier had a diameter of two inches $(0.0508 \mathrm{~m})$ and a freeboard with diameter of

92 four inches $(0.1016 \mathrm{~m})$. The overall height of the gasifier was 30 inches $(0.762 \mathrm{~m})$, while the

93 freeboard was 6 inches $(0.1524 \mathrm{~m})$ high. The biomass was stored in the hopper and fed into the

94 gasifier with the help of the auger feeder. Oxygen and nitrogen were used for gasification as the

95 oxidizing and the fluidizing agent, respectively. The flow rate of the nitrogen supplied for

96 fluidization was kept constant at $15 \mathrm{l} / \mathrm{min}$ and the corresponding superficial velocity was 0.12

$97 \mathrm{~m} / \mathrm{s}$ with Reynolds number of 1.11 at NTP. The flow rate of oxygen supplied was varied to

98 achieve the target ER. ER was defined as the ratio of the actual amount of oxygen supplied to the

99 gasifier to the amount of oxygen required for complete combustion of a given quantity of

100 biomass [21].

\section{$101 \quad 2.3$ Data sampling and analysis}

102 Char and liquid condensate yields were gravimetrically calculated and the char was further 103 analyzed using Perkin Elmer elemental analyzer for elemental composition. Tar collection 104 method has been described in details in published document [21]. This tar collected was later 105 analyzed using an Agilent GC-FID. The GC inlet and FID detector temperature were both 106 maintained at $250^{\circ} \mathrm{C}$ and the oven ramped at $5^{\circ} \mathrm{C} / \mathrm{min}$ to $250^{\circ} \mathrm{C}$. Gas components $\left(\mathrm{CO}, \mathrm{CO}_{2}, \mathrm{CH}_{4}\right.$, $107 \mathrm{H}_{2}, \mathrm{C}_{2} \mathrm{H}_{2}$, and $\mathrm{C}_{2} \mathrm{H}_{4}$ ) and contaminants ( $\mathrm{HCl}, \mathrm{HF}, \mathrm{NH}_{3}, \mathrm{HCN}, \mathrm{SO}_{2} \mathrm{COS}$ ) were collected as

108 discussed in details by Abdoulmoumine et al. [21]. The cold gas efficiency was calculated from 109 syngas composition as shown in Eq. 1. It is defined as the ratio of the sum of the heating values 110 (LHV) of the primary syngas components to that of the LHV (which was calculated from HHV) 111 of the biomass. This efficiency showed how much energy in the biomass was converted to useful 112 syngas components. 


\section{$114 \quad 2.4$ Experimental design and statistical analysis}

115 Several studies $[14,16,21]$ have reported gasification with an ER ranging from 0.2 to 0.4 and a 116 temperature range of 600 to $900^{\circ} \mathrm{C}$. In this study, the experiments were carried out at an ER of

1170.25 at 790,935 , and $1000^{\circ} \mathrm{C}$ and $\mathrm{ER}$ of $0.20,0.25$, and 0.30 at $935^{\circ} \mathrm{C}$ to study the effect of the

118 temperature and the ER on the gasification products, respectively. A limited number of raw pine

119 gasification experiments were performed at feed rate of approximately $9 \mathrm{~g} / \mathrm{min}$ to compare the 120 results with the torrefied pine under similar conditions (ER 0.25 , temperature $935^{\circ} \mathrm{C}$ and feed 121 rate $\sim 9 \mathrm{~g} / \mathrm{min})$. The data presented in Section 3 are the average of three runs for every ER and 122 temperature unless otherwise noted. Statistical analysis was carried out using 1-way ANOVA 123 with an alpha of $5 \%$ (95\% confidence interval) to determine the significance of ER and 124 temperature on syngas products, and the analysis was performed using Minitab ${ }^{\circledR}$. It is important 125 to note that only one tar datum point was collected for each condition.

\section{3. Results and discussion}

127 In this section, effect of temperature and ER on product yield, syngas composition, syngas 128 energy, cold gas efficiency and contaminants have been discussed thoroughly. The biomass 129 characterization and the syngas profile obtained for various process conditions have also been 130 discussed.

\section{$131 \quad 3.1$ Biomass characterization}

132 Table 1 summarizes the properties of torrefied and raw pine used in this study. Due to 133 torrefaction, the fixed carbon increased in the sample. An increase in carbon by percent weight 
134 was also observed in ultimate analysis of torrefied pine. The proximate and ultimate analyses of

135 this feedstock are consistent with the typical values reported for torrefied biomass [16, 18, 22].

136 Also, the heating value of $23.60 \pm 0.13 \mathrm{MJ} / \mathrm{kg}$ (dry basis) is in agreement with those reported for

137 the torrefied pine by other studies $[9,15,17,23]$. The bulk and particle density of the torrefied 138 pine were found to be $1474.46 \pm 10.48 \mathrm{~kg} / \mathrm{m}^{3}$ and $489.91 \pm 3.88 \mathrm{~kg} / \mathrm{m}^{3}$, respectively. The average 139 particle size $\left(\mathrm{d}_{50}\right)$ obtained was $0.289 \pm 0.01 \mathrm{~mm}$. Similarly, the bulk and particle density of the 140 raw pine were $1469.27 \pm 2.41 \mathrm{~kg} / \mathrm{m}^{3}$ and $224 \pm 0.54 \mathrm{~kg} / \mathrm{m}^{3}$, respectively. The average particle size $141\left(\mathrm{~d}_{50}\right)$ of raw pine used in this study was $0.468 \pm 0.044 \mathrm{~mm}$.

Table 1: Proximate and ultimate analyses of raw and torrefied pine

\begin{tabular}{|c|c|c|c|c|c|c|c|c|c|}
\hline & \multicolumn{4}{|c|}{ Proximate analysis, $\mathrm{db}$} & \multicolumn{3}{|c|}{ Ultimate analysis, daf } & \multirow[b]{2}{*}{$\mathrm{O}$} & \multirow[b]{2}{*}{$\begin{array}{c}\text { Moistur } \\
\mathrm{e}, \%^{\mathrm{a}}\end{array}$} \\
\hline Sample & Ash & VM & $\mathrm{FC}$ & $\mathrm{C}$ & $\mathrm{H}$ & $\mathrm{N}$ & $\mathrm{S}$ & & \\
\hline $\begin{array}{l}\text { Raw } \\
\text { pine }\end{array}$ & $\begin{array}{c}0.53 \pm 0 . \\
21\end{array}$ & $\begin{array}{c}84.94 \pm 3 \\
16\end{array}$ & $\begin{array}{c}14.53 \pm 3 . \\
03\end{array}$ & $\begin{array}{c}51.13 \pm 0 . \\
03\end{array}$ & $\begin{array}{c}7.15 \pm 0 . \\
02\end{array}$ & $\begin{array}{c}0.44 \pm 0 . \\
02\end{array}$ & $\begin{array}{c}0.32 \pm 0 . \\
01\end{array}$ & $\begin{array}{c}40.96 \pm 0 \\
25\end{array}$ & $\begin{array}{c}7.94 \pm 0 \\
16\end{array}$ \\
\hline $\begin{array}{l}\text { Torrefi } \\
\text { ed pine }\end{array}$ & $\begin{array}{c}1.17 \\
\pm 0.11 \\
\end{array}$ & $\begin{array}{r}75.74 \\
\pm 0.22 \\
\end{array}$ & $\begin{array}{l}23.10 \\
\pm 0.32 \\
\end{array}$ & $\begin{array}{l}58.61 \\
\pm 0.40 \\
\end{array}$ & $\begin{array}{c}6.27 \\
\pm 0.27 \\
\end{array}$ & $\begin{array}{c}0.35 \\
\pm 0.01 \\
\end{array}$ & $\begin{array}{c}0.31 \\
\pm 0.04 \\
\end{array}$ & $\begin{array}{l}34.46 \\
\pm 0.17 \\
\end{array}$ & $\begin{array}{c}6.73 \\
\pm 0.26 \\
\end{array}$ \\
\hline
\end{tabular}
received

Biomass composition analysis of two samples are presented in Table 2. The total hemicellulose 148 and cellulose contents decreased from $16.39 \%$ to $10.35 \%$ and from $50.83 \%$ to $39.51 \%$, 149 respectively. This decrease was due to decomposition of cellulose and hemicellulose around $150300^{\circ} \mathrm{C}[9,16,17]$. The high content of Klason lignin was due to decomposition of 151 polysaccharides and more condensation reactions of biopolymers as a result of torrefaction 152 process [24]. Biomass composition reported in Table 2 agreed well with the literature [9] [24].

Table 2. Component analysis of biomass samples ${ }^{\mathrm{a}}$

\begin{tabular}{|c|c|c|c|c|c|c|}
\hline Biomass & Cellulose & \multicolumn{4}{|c|}{ Hemicellulose \% } & Klason \\
\hline sample & Glucan & Galactan & Arabinan & Mannan & Total & $\%$ \\
\hline
\end{tabular}




\begin{tabular}{cccccccc}
\hline Pine & $50.83 \pm 0.15$ & 4.23 & 1.69 & 1.79 & 8.68 & 16.39 & 29.75 \\
& & \pm 0.05 & \pm 0.01 & \pm 0.01 & \pm 0.06 & \pm 0.14 & \pm 0.89 \\
Torrefied & $39.51 \pm 6.97$ & 2.02 & 1.00 & 2.52 & 4.82 & 10.35 & 45.00 \\
pine & & \pm 0.31 & \pm 0.09 & \pm 2.15 & \pm 2.94 & \pm 6.11 & \pm 0.02 \\
\hline
\end{tabular}

${ }^{a}$ Cellulose, hemicellulose and lignin are calculated on extractive free basis.

\subsection{Syngas profile}

157 Syngas was analyzed continuously for its composition. The syngas profile obtained for each run 158 were similar to those reported by Abdoulmoumine et al. [21] for raw pine. It was observed that 159 the steady state was reached faster with an increase in temperature, while no such effect was 160 observed with an increase in ER. Steady state was obtained around 20 to 30 minutes into the run 161 and the experiments were run from at least 120 minutes. Only the steady state data were used for 162 the calculations, which agreed well with those reported in some of the previous studies [25] [21].

\section{$163 \quad 3.3$ Effect of temperature and equivalence ratio}

164 Table 3 summarizes the product yield, gas composition, gas energy, carbon conversion, cold gas

165 efficiency and energy content of the syngas as obtained in this study. Subsequent sections will

166 further discuss these responses as well as the selected contaminants measured in details.

167 Table 3: Gasification products obtained as a function of temperature (with ER 0.25) and ER (at 168 temperature $935^{\circ} \mathrm{C}$ ) with sand as bed material ${ }^{\mathrm{a}}$

\begin{tabular}{lcccccc}
\hline & \multicolumn{3}{c}{ Temperature, ${ }^{\circ}$ C } & ER \\
\hline \multirow{4}{*}{ Gas } & 790 & 935 & 1000 & 0.20 & 0.25 & 0.30 \\
& \multicolumn{5}{c}{ Product yield, \% } \\
Char & 69.21 & 79.62 & 80.56 & 77.89 & 79.62 & 79.31 \\
& $\pm 0.85^{\mathrm{B}}$ & $\pm 5.17^{\mathrm{A}}$ & $\pm 2.57^{\mathrm{A}}$ & $\pm 3.46^{\mathrm{X}}$ & $\pm 5.17^{\mathrm{X}}$ & $\pm 2.54^{\mathrm{X}}$ \\
Liquid & 12.98 & 7.33 & 6.99 & 9.33 & 7.33 & 5.43 \\
& $\pm 0.80^{\mathrm{A}}$ & $\pm 3.12^{\mathrm{B}}$ & $\pm 1.19^{\mathrm{B}}$ & $\pm 3.38^{\mathrm{X}}$ & $\pm 3.12^{\mathrm{X}}$ & $\pm 1.43^{\mathrm{X}}$ \\
& 17.82 & 13.04 & 12.44 & 12.77 & 13.04 & 15.04 \\
CO & $\pm 0.91^{\mathrm{A}}$ & $\pm 2.10^{\mathrm{A}, \mathrm{B}}$ & $\pm 1.57^{\mathrm{B}}$ & $\pm 3.38^{\mathrm{X}}$ & $\pm 2.10^{\mathrm{X}}$ & $\pm 1.12^{\mathrm{X}}$ \\
& 9.32 & 11.78 & 12.26 & 11.27 & 11.78 & 12.85 \\
& $\pm 0.85^{\mathrm{A}}$ & $\pm 2.31^{\mathrm{A}}$ & $\pm 1.03^{\mathrm{A}}$ & $\pm 0.99^{\mathrm{X}}$ & $\pm 2.31^{\mathrm{X}}$ & $\pm 1.86^{\mathrm{X}}$ \\
\hline
\end{tabular}




\begin{tabular}{|c|c|c|c|c|c|c|}
\hline $\mathrm{CO}_{2}$ & $\begin{array}{r}10.97 \\
\pm 0.53^{\mathrm{A}}\end{array}$ & $\begin{array}{c}10.09 \\
\pm 0.16^{\mathrm{B}}\end{array}$ & $\begin{array}{c}9.39 \\
\pm 0.95^{\mathrm{B}}\end{array}$ & $\begin{array}{c}8.39 \\
\pm 0.54^{\mathrm{Z}}\end{array}$ & $\begin{array}{c}10.09 \\
\pm 0.16^{\mathrm{Y}}\end{array}$ & $\begin{array}{c}11.59 \\
\pm 0.39^{\mathrm{X}}\end{array}$ \\
\hline $\mathrm{CH}_{4}$ & $\begin{array}{r}11.15 \\
\pm 0.90^{\mathrm{A}}\end{array}$ & $\begin{array}{c}5.39 \\
\pm 0.91^{\mathrm{B}}\end{array}$ & $\begin{array}{c}4.62 \\
\pm 0.11^{\mathrm{B}}\end{array}$ & $\begin{array}{c}5.76 \\
\pm 0.84^{\mathrm{X}}\end{array}$ & $\begin{array}{c}5.39 \\
\pm 0.91^{\mathrm{X}}\end{array}$ & $\begin{array}{c}4.89 \\
\pm 0.89^{\mathrm{X}}\end{array}$ \\
\hline $\boldsymbol{H}_{2}$ & $\begin{array}{c}3.54 \\
\pm 1.03^{\mathrm{B}}\end{array}$ & $\begin{array}{c}6.91 \\
\pm 0.76^{\mathrm{A}}\end{array}$ & $\begin{array}{c}7.61 \\
\pm 0.31^{\mathrm{A}}\end{array}$ & $\begin{aligned} & 7.28 \\
\pm & 0.05^{\mathrm{X}}\end{aligned}$ & $\begin{array}{r}6.91 \\
\pm 0.76^{\mathrm{X}}\end{array}$ & $\begin{array}{c}6.74 \\
\pm 0.99^{\mathrm{X}}\end{array}$ \\
\hline $\mathrm{C}_{2} \mathrm{H}_{2}$ & $\begin{array}{c}0.05 \\
\pm 0.001^{\mathrm{A}}\end{array}$ & $\begin{array}{c}0.11 \\
\pm 0.03^{\mathrm{A}}\end{array}$ & $\begin{array}{c}0.10 \\
\pm 0.02^{\mathrm{A}}\end{array}$ & $\begin{array}{c}0.11 \\
\pm 0.001^{\mathrm{X}}\end{array}$ & $\begin{array}{c}0.11 \\
\pm 0.03^{\mathrm{X}}\end{array}$ & $\begin{array}{c}0.11 \\
\pm 0.01^{\mathrm{X}}\end{array}$ \\
\hline $\mathrm{C}_{2} \mathrm{H}_{4}$ & $\begin{array}{c}0.84 \\
\pm 0.17^{\mathrm{C}}\end{array}$ & $\begin{array}{c}1.16 \\
\pm 0.07^{\mathrm{A}}\end{array}$ & $\begin{array}{c}0.41 \\
\pm 0.01^{\mathrm{B}}\end{array}$ & $\begin{array}{c}0.48 \\
\pm 0.01^{Y}\end{array}$ & $\begin{array}{c}1.16 \\
\pm 0.07^{\mathrm{X}}\end{array}$ & $0.95 \pm 0.2^{\mathrm{X}}$ \\
\hline \multicolumn{7}{|c|}{ Efficiency, \% } \\
\hline Cold gas & $\begin{array}{c}73.50 \\
\pm 11.47^{\mathrm{A}}\end{array}$ & $\begin{array}{c}52.12 \\
\pm 12.64^{\mathrm{A}, \mathrm{B}}\end{array}$ & $\begin{array}{c}49.67 \\
\pm 4.82^{\mathrm{B}}\end{array}$ & $\begin{array}{l}52.55 \\
\pm 8.35^{\mathrm{X}}\end{array}$ & $\begin{array}{c}52.13 \\
\pm 12.64^{\mathrm{X}}\end{array}$ & $\begin{array}{c}54.14 \\
\pm 5.05^{\mathrm{X}}\end{array}$ \\
\hline \multicolumn{7}{|c|}{ Syngas energy } \\
\hline $\begin{array}{l}\text { Energy content, } \\
M J / \mathrm{Nm}^{3}\end{array}$ & $\begin{array}{c}6.29 \\
\pm 0.23^{\mathrm{A}}\end{array}$ & $\begin{array}{c}4.51 \\
\pm 0.69^{\mathrm{B}}\end{array}$ & $4.3 \pm 0.13^{\mathrm{B}}$ & $\begin{array}{c}4.64 \\
\pm 0.45^{\mathrm{x}}\end{array}$ & $\begin{array}{c}4.51 \\
\pm 0.69^{x}\end{array}$ & $\begin{array}{c}4.43 \\
\pm 0.37^{\mathrm{X}}\end{array}$ \\
\hline \multicolumn{7}{|c|}{ Contaminant concentration (ppm Volume) } \\
\hline Ammonia & $\begin{array}{r}459.82 \\
\pm 22.64^{\mathrm{A}}\end{array}$ & $\begin{array}{c}637.23 \\
\pm 25.07^{\mathrm{A}}\end{array}$ & $\begin{array}{c}529.75 \\
\pm 20.10^{\mathrm{A}}\end{array}$ & $\begin{array}{c}564.77 \\
\pm 45.65^{\mathrm{X}}\end{array}$ & $\begin{array}{c}637.23 \\
\pm 25.07^{\mathrm{X}}\end{array}$ & $\begin{array}{r}622.79 \\
\pm 12.04^{\mathrm{X}}\end{array}$ \\
\hline Hydrogen cyanide & $\begin{array}{c}89.47 \\
\pm 4.21^{\mathrm{B}}\end{array}$ & $\begin{array}{r}175.95 \\
\pm 13.24^{\mathrm{A}}\end{array}$ & $\begin{array}{r}165.50 \\
\pm 19.43^{\mathrm{A}}\end{array}$ & $\begin{array}{c}183.63 \\
\pm 30.82^{\mathrm{X}}\end{array}$ & $\begin{array}{r}175.95 \\
\pm 13.25^{\mathrm{X}}\end{array}$ & $\begin{array}{r}162.82 \\
\pm 19.14^{\mathrm{X}}\end{array}$ \\
\hline Hydrogen & 2.29 & 0.90 & 0.33 & 1.28 & 0.90 & 1.16 \\
\hline chloride & $\pm 1.09^{\mathrm{A}}$ & $\pm 0.15^{\mathrm{A}}$ & $\pm 0.03^{\mathrm{A}}$ & $\pm 0.07^{\mathrm{X}}$ & $\pm 0.15^{\mathrm{X}}$ & $\pm 0.25^{\mathrm{X}}$ \\
\hline Hydrogen & 0.15 & 0.27 & 0.27 & 0.28 & 0.27 & 0.28 \\
\hline fluoride & $\pm 0.01^{\mathrm{A}}$ & $\pm 0.06^{\mathrm{A}}$ & $\pm 0.08^{\mathrm{A}}$ & $\pm 0.08^{\mathrm{X}}$ & $\pm 0.06^{\mathrm{X}}$ & $\pm 0.04^{\mathrm{X}}$ \\
\hline Carbonyl sulfide & $\begin{array}{c}16.41 \\
\pm 0.90^{\mathrm{A}}\end{array}$ & $\begin{array}{c}11.48 \\
\pm 4.25^{\mathrm{A}, \mathrm{B}}\end{array}$ & $\begin{array}{c}5.38 \\
\pm 3.24^{\mathrm{B}}\end{array}$ & $\begin{array}{c}6.41 \\
\pm 3.72^{\mathrm{X}}\end{array}$ & $\begin{array}{c}11.48 \\
\pm 4.25^{\mathrm{X}}\end{array}$ & $\begin{array}{l}11.97 \\
\pm 3.9^{X}\end{array}$ \\
\hline Sulfur dioxide & $\begin{array}{r}86.29 \\
\pm 3.38^{\mathrm{A}}\end{array}$ & $\begin{array}{r}105.44 \\
\pm 21.58^{\mathrm{A}}\end{array}$ & $\begin{array}{r}82.09 \\
\pm 4.85^{\mathrm{A}}\end{array}$ & $\begin{array}{l}109.29 \\
\pm 4.27^{\mathrm{X}}\end{array}$ & $\begin{array}{r}105.44 \\
\pm 21.58^{\mathrm{X}}\end{array}$ & $\begin{array}{c}93.13 \\
\pm 9.90^{\mathrm{X}}\end{array}$ \\
\hline
\end{tabular}

${ }^{\mathrm{a}}$ Effect of temperature (superscript A, B and C) and ER (superscript X, Y and Z) were analyzed independently and interaction between them was not studied. Means with same superscripts are not statistically different $(\mathrm{P}$-value $>0.05)$ based on a one-way ANOVA test.

\section{$170 \quad$ 3.3.1 Product yield}

171 Char, condensate liquid and gas yields were depended on the operating conditions. The char

172 yield decreased with an increase in temperature due to increase in char reactivity (Table 3). This

173 resulted in increase in gas yield with an increase in temperature. The liquid condensate yield also

174 reduced with an increase in temperature. This was due to increase in steam reforming of char and

175 syngas with an increase in temperature. The change was significant when the temperature was 
176 increased from 790 to $935^{\circ} \mathrm{C}$. Similar trends were observed with pine gasification [21]. An

177 increase in gas yield with increase in temperature was also reported by Narvaez et al. [26] for saw

178 dust and for four different biomass samples by Carpenter et al.[25]. Thus, torrefied pine followed

179 similar trend to the raw biomass samples.

180 As the ER is increased, higher oxygen availability influenced the oxidation reactions, resulting in

181 increase in oxidation products in syngas. Table 3 shows that the reduction in char yield and

182 increase in liquid yield with increase in ER are not statistically significant in the range of ER

183 under study. Similarly, an increase in gas yield was not significant. Few other studies have

184 observed trends similar to those observed in this study for the char yield as the ER increased [21,

185 27]. The increase in the gas yield was also observed for pine gasification [21] and also agreed

186 with simulation results for fluidized bed gasifier [21, 27].

187 The performance of torrefied pine was compared with raw pine under the same gasification

188 conditions $\left(935^{\circ} \mathrm{C}, \mathrm{ER}=0.25\right.$, feeding rate $\left.\sim 9 \mathrm{~g} / \mathrm{min}\right)$ and shown in Table 4 . It was observed that

189 even though the gas yields were similar for both samples, the char yield was higher for torrefied

190 pine, this was due to lower char reactivity of the torrefied pine [28]. On the other hand, higher

191 liquid yield from the raw pine could also due to slightly higher moisture content $(7.94 \pm 0.16)$ in

192 it as compared to the torrefied pine $(6.73 \pm 0.26)$.

193 Table 4: Product yield for raw pine and torrefied pine at $935^{\circ} \mathrm{C}$, ER 0.25 and feed rate $\sim 9 \mathrm{~g} / \mathrm{min}$

\begin{tabular}{cccc}
\hline Biomass sample & \multicolumn{3}{c}{ Product yield } \\
\hline & Gas yield, $\%$ & Char yield, $\%$ & Liquid yield, \% \\
Pine & $78.10 \pm 1.25$ & $3.45 \pm 0.85$ & $18.44 \pm 1.44$ \\
Torrefied pine & $79.62 \pm 5.17$ & $7.33 \pm 3.12$ & $13.04 \pm 2.10$ \\
\hline
\end{tabular}




\section{$194 \quad$ 3.3.2 Syngas composition}

195 Volumetric syngas composition as a function of temperature and ER are shown in Table 3,

196 whereas Figure 1 illustrates the variation of component yield ( $\mathrm{g} / \mathrm{kg}$ dry biomass) as a function of

197 the temperature and ER.

198 Effect of temperature:

199 As seen in the Table 3 and Figure 1a, the average concentration and yield of $\mathrm{CO}$ and $\mathrm{H}_{2}$ 200 increased with an increase in temperature. However, the concentration of $\mathrm{CO}$ was statistically 201 not significant but $\mathrm{H}_{2}$ concentration was increased when the temperature was increased from 790 202 to $935^{\circ} \mathrm{C}$. On the other hand, $\mathrm{CO}_{2}$ and $\mathrm{CH}_{4}$ reduced significantly with an increase in temperature 203 from 790 to $935^{\circ} \mathrm{C}$. The reduction in $\mathrm{CO}_{2}$ and the corresponding in increase in $\mathrm{CO}$ (even though 204 it was statistically not significant but the mean values were increasing) could be explained by 205 Boudouard reaction as shown in Eq. 2. Furthermore, the steam reforming of methane into $\mathrm{H}_{2}$ and 206 CO, explained by Eq. 3, at higher temperature was responsible for its reduction.

$$
\mathrm{C}+\mathrm{CO}_{2} \quad \leftrightarrow \quad 2 \mathrm{CO}
$$$$
\Delta \mathrm{H}^{\circ} 298=+172 \mathrm{~kJ} / \mathrm{mol}
$$

209 The increase in the concentration of $\mathrm{CO}$ and $\mathrm{H}_{2}$ agrees with that reported in the literature for

210 switchgrass and other biomass feedstocks [16, 21, 25, 26]. Although an increase in $\mathrm{C}_{2} \mathrm{H}_{2}$ was

211 noticed, it was not statistically significant with an increase in temperature. The $\mathrm{C}_{2} \mathrm{H}_{4}$ yields on

212 the other hand showed a peak at $935^{\circ} \mathrm{C}$. The increase in the acetylene and the ethylene

213 production could be due to the reaction of carbon and hydrogen present in the char, which

214 increases with an increase in temperature from 790 to $935^{\circ} \mathrm{C}$. At $1000^{\circ} \mathrm{C}$ steam reforming of 215 these compounds resulted in reduction of the yield and concentrations. The values reported 
216 agreed well with those reported previously [21, 25, 29]. Thus, increase in temperature had 217 similar effect on performance of torrefied pine and raw biomass samples.
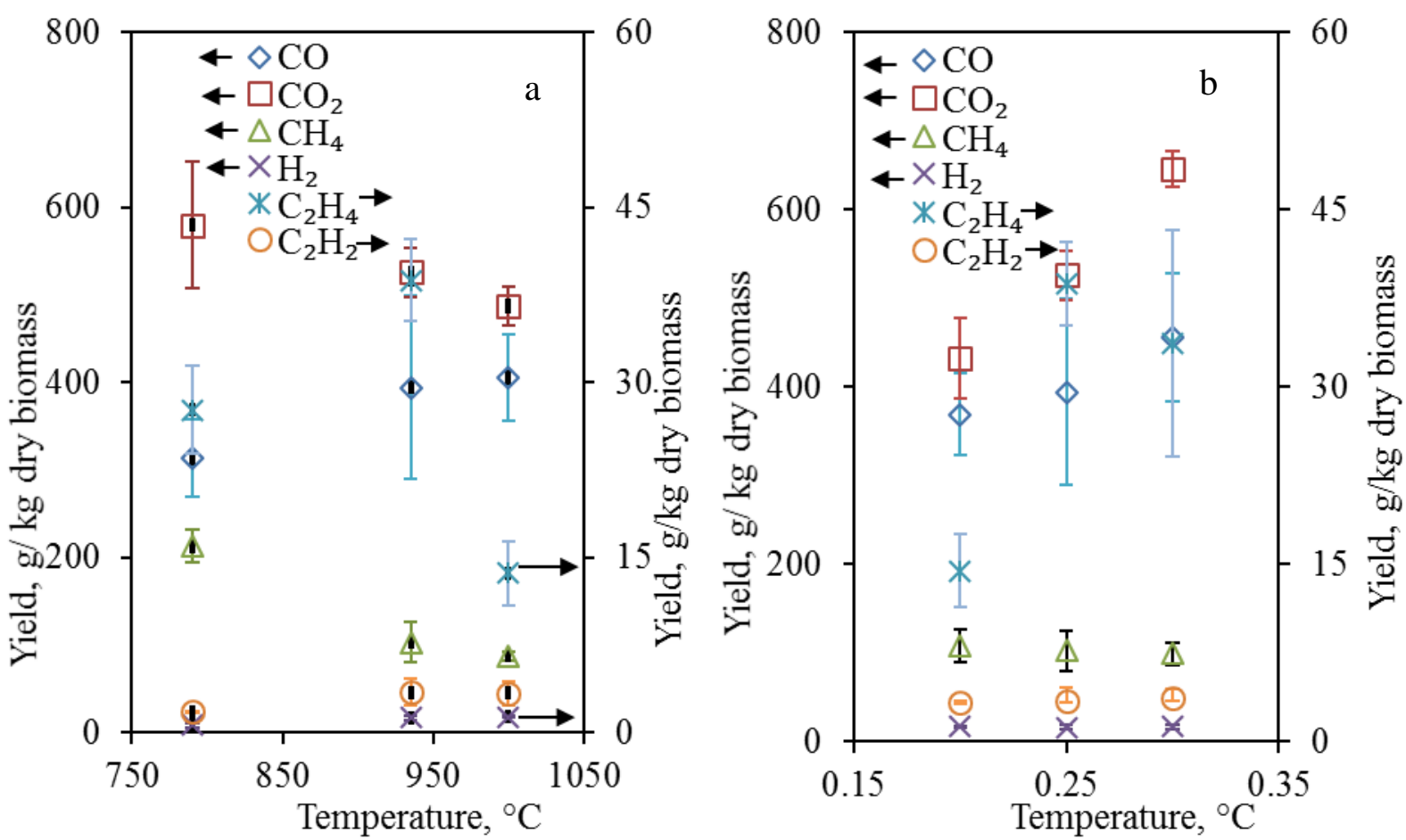

Figure 1: Effect of (a) temperature at $0.24 \mathrm{ER}$ and (b) ER at $935^{\circ} \mathrm{C}$ on syngas composition Effect of ER:

221 Table 3 and Figure $1 \mathrm{~b}$ show the variation in the yields of syngas components as a function ER

222 with $\mathrm{CO}_{2}$ significantly increasing as ER increased. This was due to higher oxidation of char, 223 which was also responsible for slight increase in $\mathrm{CO}$, though this was not statistically significant.

224 The increase in oxygen reduced methane and hydrogen concentration, though not significantly in

225 the range of ER studied. $\mathrm{C}_{2} \mathrm{H}_{2}$ was not affected with an increase in ER, whereas $\mathrm{C}_{2} \mathrm{H}_{4}$ showed an 226 increase with an increase in the ER. Pine gasification study reported a decrease in the $\mathrm{CO}, \mathrm{CH}_{4}$ 227 and $\mathrm{H}_{2}$ concentrations, and a significant increase in $\mathrm{CO}_{2}$ in the range of 0.15 to 0.35 ER [21]. 228 The presence of higher amount of hemicellulose in raw biomass makes the resulting char more 229 reactive as compared to the torrefied pine where hemicellulose is comparatively much lower 
230 [28]. The $\mathrm{CO}$ and $\mathrm{H}_{2}$ yields agreed well with those reported for torrefied switchgrass gasification

231 using a TGA [16]. However, the methane yields were almost twice of those reported in the same

232 study probably due to the difference in TGA and bench scale setup.

233 Furthermore, a comparison with raw pine was made under similar operating conditions as shown

234 in Table 5. The volumetric syngas compositions were slightly better with raw pine than torrefied

235 samples. Energy content and cold gas efficiency were higher in the case of raw pine than with

236 torrefied samples. Thus, it can be concluded that the change in biomass composition due to

237 torrefaction did not improve syngas composition and energy value. When compared with

238 torrefied pellets gasified in downdraft gasifiers [14, 23] with much higher feed rate (almost 30 to

23960 times that of bench-scale fluidized bed gasifier), significantly higher concentrations of CO

240 and $\mathrm{H}_{2}$, but much lower $\mathrm{CH}_{4}$ were observed. This was probably due to the downdraft gasifier

241 design which helped thermally decompose the hydrocarbons resulting in reduction of $\mathrm{CH}_{4}$.

242 Table 5: Comparison of syngas gas composition obtained from torrefied and raw pine

\begin{tabular}{|c|c|c|c|c|}
\hline & $\begin{array}{l}\text { Torrefied } \\
\text { pine }\end{array}$ & Raw Pine & $\begin{array}{l}\text { Torrefied } \\
\text { pine } \\
\text { pellets[17] }\end{array}$ & $\begin{array}{c}\text { Torrefied } \\
\text { Pellets[14] }\end{array}$ \\
\hline $\begin{array}{l}\text { Temperature, } \\
{ }^{\circ} \mathrm{C}\end{array}$ & 935 & 935 & 800 & 800 \\
\hline ER & 0.25 & 0.25 & 0.28 & 0.28 \\
\hline Mean Feed rate & $9.3 \mathrm{~g} / \mathrm{min}$ & $9.8 \mathrm{~g} / \mathrm{min}$ & $383.5 \mathrm{~g} / \mathrm{min}$ & $583.3 \mathrm{~g} / \mathrm{min}$ \\
\hline \multicolumn{5}{|c|}{ Composition, vol \% } \\
\hline $\mathrm{CO}, \%$ & $11.78 \pm 2.31$ & $13.89 \pm 0.60$ & $24.51 \pm 0.62$ & 29 \\
\hline $\mathrm{CO}_{2}, \%$ & $10.09 \pm 0.16$ & $9.24 \pm 0.14$ & $7.88 \pm 1.33$ & 6.7 \\
\hline $\mathrm{CH}_{4}, \%$ & $5.39 \pm 0.91$ & $6.81 \pm 0.30$ & $1.49 \pm 0.54$ & 1.6 \\
\hline $\mathrm{H}_{2}, \%$ & $6.91 \pm 0.76$ & $6.03 \pm 0.21$ & $15.13 \pm 0.25$ & 10.3 \\
\hline $\mathrm{C}_{2} \mathrm{H}_{4}, \%$ & $1.16 \pm 0.07$ & $1.25 \pm 0.34$ & n.r. & 0.2 \\
\hline $\mathrm{C}_{2} \mathbf{H}_{2}, \%$ & $0.11 \pm 0.03$ & $0.12 \pm 0.02$ & n.r. & n.r. \\
\hline $\begin{array}{l}\text { Energy content } \\
\left(\mathrm{MJ} / \mathbf{N m}^{3}\right)\end{array}$ & $4.51 \pm 0.69$ & $5.24 \pm 0.2$ & $5.61 \pm 0.06$ & 5.79 \\
\hline $\begin{array}{l}\text { Cold gas } \\
\text { efficiency, \% }\end{array}$ & $52.12 \pm 12.64$ & $66.46 \pm 3.10$ & $63.00 \pm 1.0$ & 75 \\
\hline
\end{tabular}




\section{$244 \quad$ 3.3.3 Syngas energy}

245 Syngas heating value or the energy content of syngas was in the range of 4.3 to $6.3 \mathrm{MJ} / \mathrm{Nm}^{3}$ as 246 seen in Table 3 and these values agreed well with that reported in literature [16, 23, 25, 26, 30].

$247 \mathrm{CH}_{4}$ is an important component in syngas, with an increase in temperature resulting in a 248 reduction in $\mathrm{CH}_{4}$. This led to decreased in syngas energy with an increase in temperature, even 249 though $\mathrm{CO}$ and $\mathrm{H}_{2}$ increased. The torrefied pine produced much higher methane at lower 250 temperature, which is advantageous if syngas is used for power application. ER did not 251 significantly affect the energy content of syngas. Since the ER did not have any significant effect 252 on $\mathrm{CO}, \mathrm{CH}_{4}$ and $\mathrm{H}_{2}$, the effect on energy content was justified. For pine studies, an increase in 253 ER resulted in a decrease in energy content. The gasification experiments carried out for 254 torrefied pine using downdraft gasifiers reported syngas $\mathrm{HHV}$ around $5.6 \mathrm{MJ} / \mathrm{Nm}^{3}$ at 255 temperature around $800^{\circ} \mathrm{C}[14,17]$. This value is slightly lower than what was obtained at $790^{\circ} \mathrm{C}$ 256 (Table 3).

\section{$257 \quad$ 3.3.4 Cold gas efficiency}

258 The cold gas efficiency decreased with an increase in the temperature; this was mostly the result

259 of decrease in methane concentration in the syngas with an increase in temperature as shown in

260 Table 3. The cold gas efficiency for downdraft gasifier was around 65 to $70 \%[16,17]$. The 261 range of the cold gas efficiency (30 to 70\%) also agreed well with the values reported for 262 fluidized bed gasifiers in the literature [14, 16, 17, 29].

263 During the gasification of torrefied pine in a $25 \mathrm{KW}_{\text {th }}$ downdraft gasifier, the carbon conversion 264 and cold gas efficiency were reported to be around $79 \%$ and $63 \%$, respectively at $800^{\circ} \mathrm{C}$ [17]. 
265 Yet another study reported carbon conversion and cold gas efficiency around $87 \%$ and $75 \%$,

266 respectively[14]. A small-scale study on torrefied switchgrass gasified in a small bench scale

267 downdraft gasifier reported increased carbon conversion at 75 to $80 \%$ and cold gas efficiency at

26850 to $55 \%$, with increase in temperature [16]. When torrefied pine was compared with raw pine

269 and switchgrass at a similar feed rate $(\sim 9 \mathrm{~g} / \mathrm{min})$, temperature $\left(935^{\circ} \mathrm{C}\right)$ and $\mathrm{ER}(0.25)$ as shown in

270 Table 4, it was noticed that pine gasification results in the highest conversion of carbon into

271 syngas. Also, raw pine produced syngas with the highest cold gas efficiency. The lower carbon

272 conversion efficiency in torrefied pine was due to high Klason lignin content in torrefied pine.

\section{$273 \quad$ 3.3.5 Contaminants}

274 Figure 2 and Figure 3 show the contaminants yield obtained as a function of temperature and ER.

275 It can be seen that ammonia was the main contaminant obtained during gasification followed by

276 hydrogen cyanide and sulfur dioxide.

277 Nitrogen contaminants $\left(\mathrm{NH}_{3}\right.$ and $\left.\mathrm{HCN}\right)$ : The yield and concentrations of nitrogen contaminants

278 (i.e., $\mathrm{HCN}$ and $\mathrm{NH}_{3}$ ) were directly proportional to the amount of nitrogen present in the biomass

279 samples.
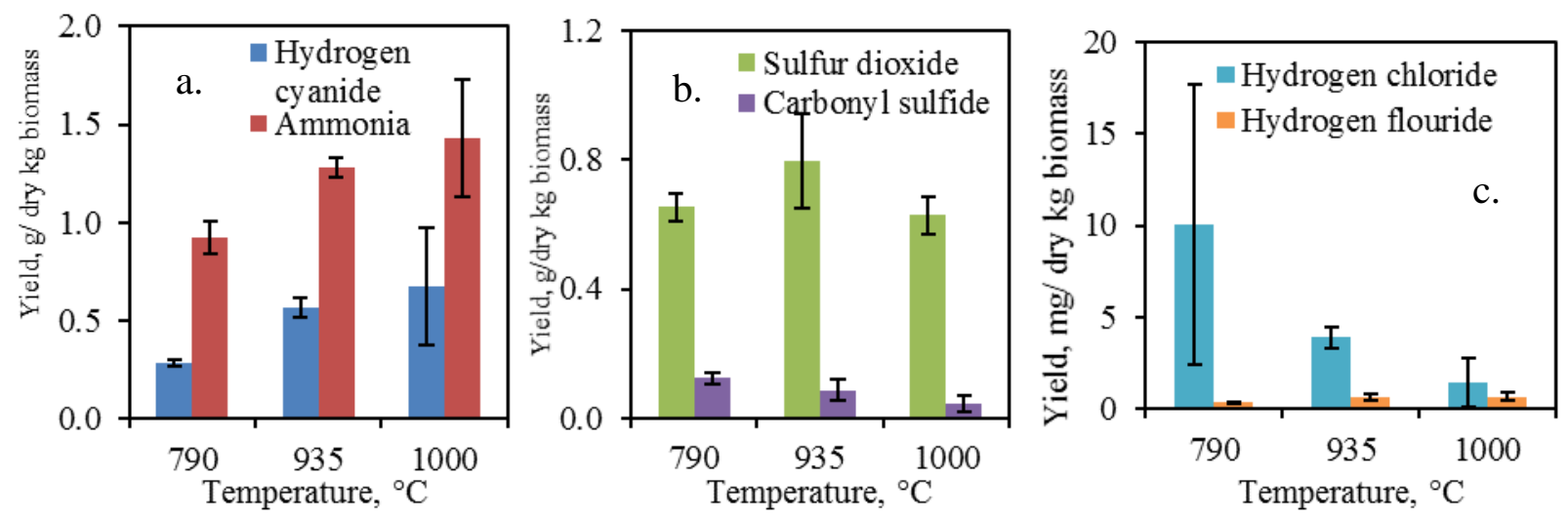

281 Figure 2: Effect of temperature on (a) $\mathrm{HCN}$ and $\mathrm{NH}_{3}$ yield, (b) $\mathrm{SO}_{2}$ and $\mathrm{COS}$ and (c) $\mathrm{HCl}$ and $\mathrm{HF}$ 
283 Figure $2 \mathrm{a}$ and Table 3 show that with an increase in temperature average yields and 284 concentrations of both $\mathrm{NH}_{3}$ and $\mathrm{HCN}$ increased even though they are not statistically significant 285 except between 790 and $935^{\circ} \mathrm{C}$ in the case of $\mathrm{HCN}$. The $\mathrm{NH}_{3}$ and $\mathrm{HCN}$ yields are result of 286 release of fuel-bound nitrogen. The increase in concentrations of $\mathrm{NH}_{3}$ and $\mathrm{HCN}$ with temperature 287 could be due to increase in release of nitrogen release with an increase in temperature. Since $\mathrm{N}_{2}$ 288 was also used as a fluidizing agent thus increase in release of nitrogen with an increase in 289 temperature could not be confirmed. This trend agreed well with that reported in the literature $290[29,31]$; however, it was opposite of the trend reported for ammonia release from raw pine[21].
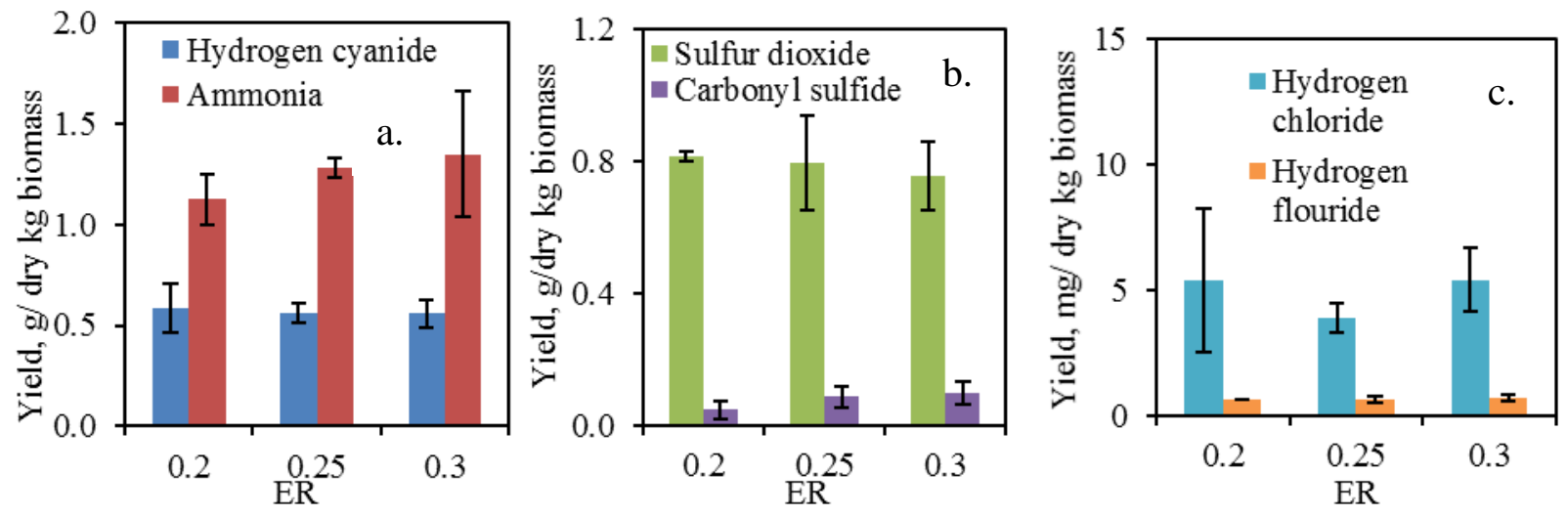

Figure 3: Effect of ER on (a) $\mathrm{HCN}$ and $\mathrm{NH}_{3}$ yield, (b) $\mathrm{SO}_{2}$ and $\mathrm{COS}$ and (c) $\mathrm{HCl}$ and $\mathrm{HF}$

294 With an increase in $\mathrm{ER}$, the $\mathrm{NH}_{3}$ and $\mathrm{HCN}$ concentration and yield, however, remained 295 statistically no different over the range of study as seen in Table 3 and Figure 3a. This trend was 296 slightly different than that observed for pine, where much higher concentrations (660 to 1000 $297 \mathrm{ppm}$ ) of ammonia were reported even at lower feeding rate[21]. When the $\mathrm{NH}_{3}$ and $\mathrm{HCN}$ values 298 obtained for all raw and torrefied pine samples under similar gasification conditions were 299 compared, it was noted that the raw biomass pine produce twice as much $\mathrm{NH}_{3}$ and one third as 
301 almost same $\mathrm{N}$ content.

302

303

304

305

306

307

308

309

310

311

312
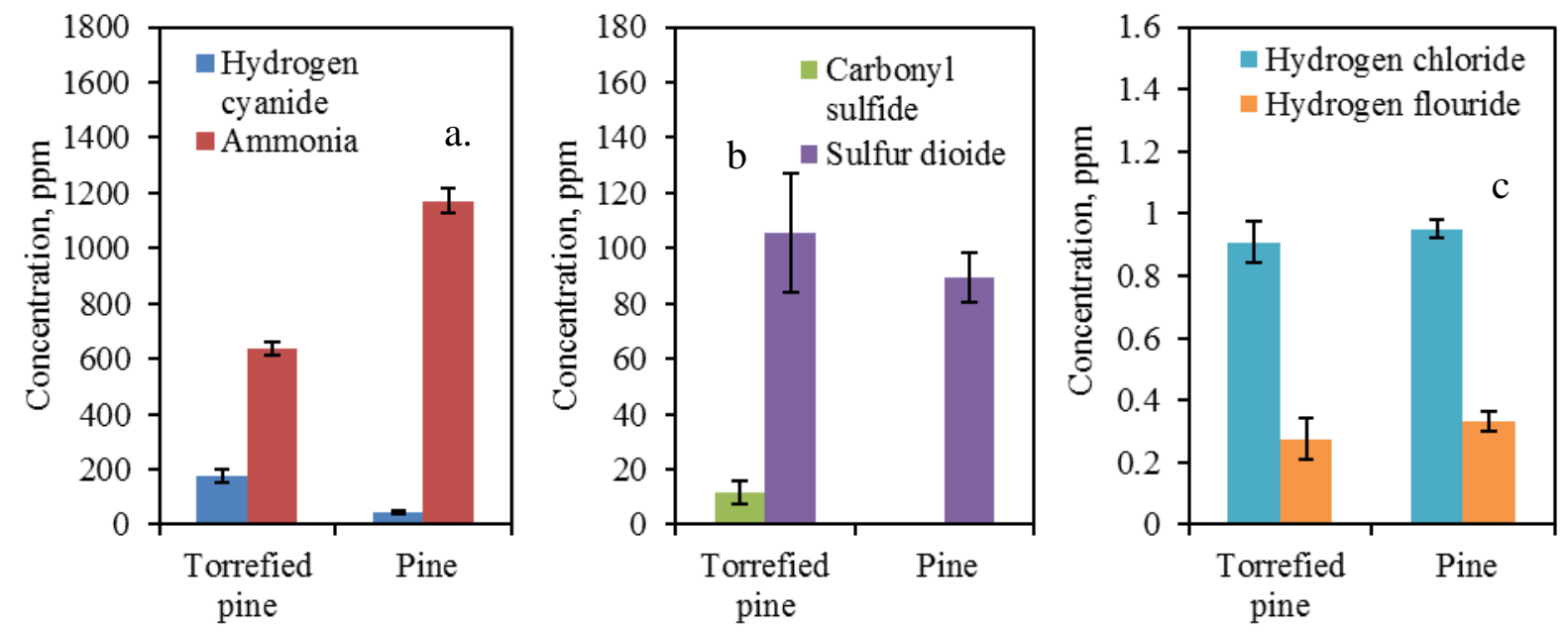

Figure 4: Concentrations of contaminants $\mathrm{NH}_{3}$ and $\mathrm{HCN}$ (a), $\mathrm{COS}$ and $\mathrm{SO}_{2}$ (b), and $\mathrm{HCl}$ and $\mathrm{HF}$ (c) at ER of 0.25 and temperature of $935^{\circ} \mathrm{C}$ with feed rate of approximately $9 \mathrm{~g} / \mathrm{min}$.

Sulfur contaminants ( $\mathrm{COS}$ and $\mathrm{SO}_{2}$ ): The effects of temperature and ER on the concentration and yield of sulfur contaminants are illustrated in Table 3 and Figure $2 b$ and Figure $3 b$. It was observed that with an increase in the temperature, the yield of $\mathrm{COS}$ and $\mathrm{SO}_{2}$ was remained unaffected. Similarly, with an increase in the ER the yield of COS and $\mathrm{SO}_{2}$ were not affected either. It is important to note that though the concentrations of $\mathrm{SO}_{2}$ were reported to be around $100 \mathrm{ppm}$; this was much lower than that reported for coal and biomass co-feeding in a fluidized bed combustor [32]. A study to understand distribution of sulfur species in gasification, reported $\mathrm{SO}_{2}$ values around 2-4 ppm and $\mathrm{COS}$ around $30 \mathrm{ppm}$ at ER 0.26 and S/B ratio of 1.3 at around $1000^{\circ} \mathrm{C}$ for corn stover in a bench-scale downdraft gasifier [33]. When the concentrations of $\mathrm{COS}$ and $\mathrm{SO}_{2}$ obtained from torrefied pine were compared with those obtained for pine under similar conditions, as shown in Figure $4 \mathrm{~b}$, it was observed that the COS concentrations were around $11.47 \mathrm{ppm}$ for torrefied pine and below detection level for raw biomass samples. This 
318 indicated that torrefied biomass favored COS production as compared to the raw biomass. $\mathrm{H}_{2} \mathrm{~S}$ is

319 the other major contaminant in the syngas; it was measured to be around $70 \mathrm{ppm}$ at temperature

$320790^{\circ} \mathrm{C}$ (at feed rate $9 \mathrm{~g} / \mathrm{min}$ ), which compared well with pine gasification $(21.70 \mathrm{ppm}$ at similar

321 temperature and biomass feed rate of $\sim 3 \mathrm{~g} / \mathrm{min}$ ) reported in Abdoulmoumine et. al. [21].

322 Halides ( $\mathrm{HCl}$ and $\mathrm{HF}$ ): Biomass consists of various amounts of chlorine and fluorine. The

323 halides present in the biomass reacted with the hydrogen to produce $\mathrm{HCl}$ and $\mathrm{HF}$, which are

324 highly reactive acids causing corrosion for downstream processes. The concentrations of $\mathrm{HCl}$

325 and HF have been reported in Table 3, and Figure 2c and 3c show the yield in $\mathrm{g} / \mathrm{kg}$ biomass on

326 dry basis as a function of temperature and ER, respectively. It can be seen that with an increase

327 in temperature, the mean concentration of $\mathrm{HCl}$ decreased, while that of $\mathrm{HF}$ increased but they are

328 statistically insignificant. Overall, the concentrations are less than $2.5 \mathrm{ppm}$. On the other hand,

329 the ER range under study does not seem to have any effect on the halide concentration. During

330 the gasification of raw pine, as reported in by Abdoulmoumine et al. (2014), it was observed that

331 the $\mathrm{HCl}$ concentration decreased with an increase in temperature[21], and this trend agreed with

332 that for torrefied biomass. Also, the concentrations of halides for pine and torrefied pine were in

333 a rather similar range. The $\mathrm{HCl}$ concentrations for coal have been reported to be around 600

$334 \mathrm{ppm}$; this corresponds to the higher chlorine content (up to $0.60 \%$ ) in coal $[34,35]$. When the

335 hydrogen halides concentrations were compared for pine, and torrefied pine under similar

336 conditions, as shown in Figure 4c, it was observed that the torrefied pine and raw pine produced

337 approximately the same amount of hydrogen halides. The torrefaction process did not affect the

338 halides present in the raw biomass and hence the similarity in hydrogen halides yields.

339 Tar: The collected tar was analyzed for benzene, toluene, ethyl benzene, o-xylene, styrene,

340 indene, phenol, 3-methyl phenol, naphthalene, 2-methyl naphthalene, and bi-phenyl. Figure 5 
341 shows the yield of each of the above mentioned compounds as a function of temperature and ER,

342 while Figure 6 shows the total tar yield as a function of temperature and ER. It is important to

343 note that the data shown in these figures were obtained from single runs and hence, a clear trend

344 was difficult to predict with an increase in temperature and ER. It was seen that with an increase

345 in temperature, the tar yield increased from $1.56 \mathrm{~g} / \mathrm{kg}$ biomass at $790^{\circ} \mathrm{C}$ to $3.87 \mathrm{~g} / \mathrm{kg}$ biomass at

$346935^{\circ} \mathrm{C}$ and with further increase in temperature it reduced to $2.08 \mathrm{~g} / \mathrm{kg}$ biomass at $1000^{\circ} \mathrm{C}$. The

347 increase in tar was a result of increase in tertiary compounds like benzene, toluene, indene,

348 styrene and naphthalene. In their seminal work on the nature of tar formation, Milne et al.[36]

349 attributed tertiary tar formation at high temperature to the thermal conversion of primary and

350 secondary tar compounds. However, at sufficiently high temperatures, all tar compounds

351 undergo thermal cracking. Therefore, it is likely that the decrease in tar concentration beyond

$352935^{\circ} \mathrm{C}$ was due to increasing thermal cracking of tar compounds.

353 The total tar yield reported was $1.94,3.87$ and $2.42 \mathrm{~g} / \mathrm{dry}$ kg biomass at ER $0.20,0.25$ and 0.30 , 354 respectively. With an increase in ER from 0.20 to 0.25 the total tar yield increased, which was 355 contradictory to what has been reported in literature $[21,25,36,37]$ and perhaps was due to the 356 small change in ER. Even though fractions of benzene and naphthalene have been reported to 357 increase above ER 0.27 [37], other compounds tend to reduce due to oxidation. With further 358 increase in ER (0.25 to 0.30) all the compounds and the total tar yield decrease, as expected. 
a.
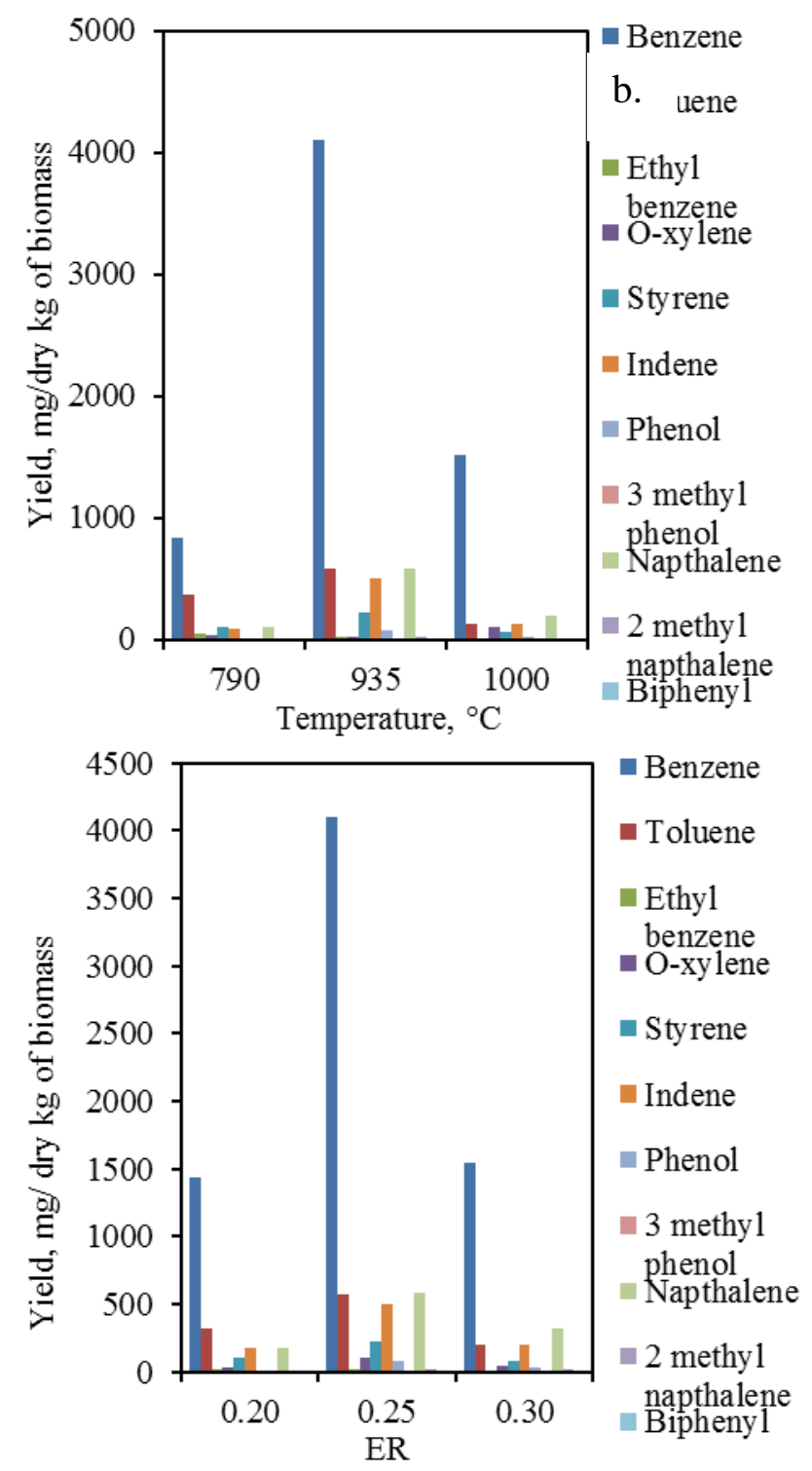

361

Figure 5 Effect of temperature (a) and ER (b) on the tar component yield
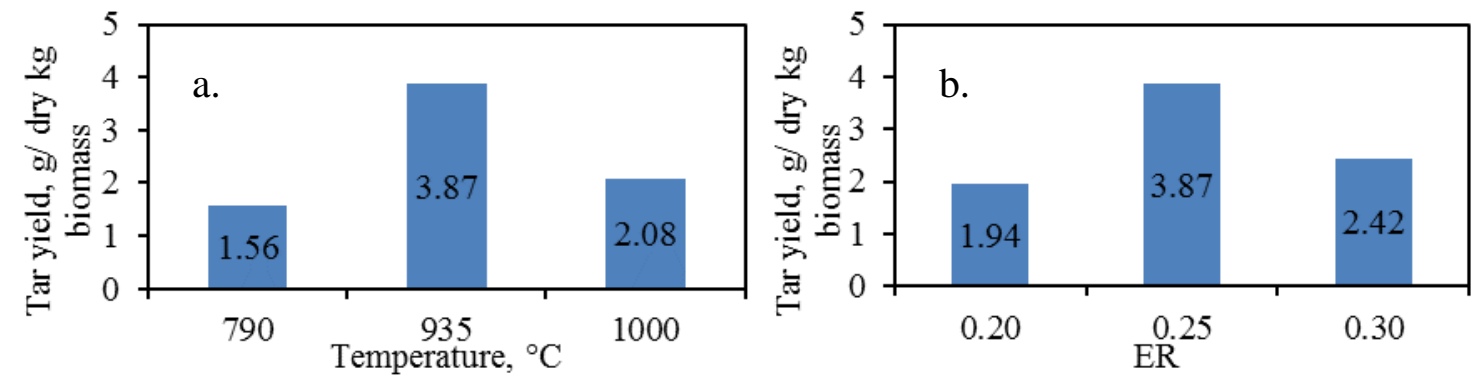

Figure 6 Effect of temperature (a) and ER (b) on total tar yield 
364 It was observed that the highest yield obtained was that of benzene followed by toluene, indene,

365 and naphthalene for all the conditions. The total and constituent yields agreed well with those

366 reported with literature $[21,25,26,38]$. When a comparison was made between tar obtained

367 from raw and torrefied pine. It was found that, for raw pine gasification tar produced was around

$3688 \mathrm{~g} / \mathrm{dry} \mathrm{kg}$ biomass and has been reported in a published article [21], at gasification temperature

$369935^{\circ} \mathrm{C}$ and ER 0.25 . While, it was observed that the torrefied pine produced less than half the

370 amount of tar obtained for pine (as shown in Figure 6a) under same temperature and ER. Thus,

371 indicating that the torrefaction of biomass helps reduce the tar yield during gasification.

\section{3.3.6 SEM images of char}

373 In order to understand the effect of gasification parameters on the biomass particles, images from

374 the scanning electron microscope (SEM) were taken. Figure 7 shows the raw pine and torrefied

375 pine at 1000x magnification. Figure 7a shows that the cell walls of the ground biomass are still

376 intact in the raw biomass, while they appear to be disintegrated due to torrefaction as seen in

377 Figure $7 b[16,39,40]$.

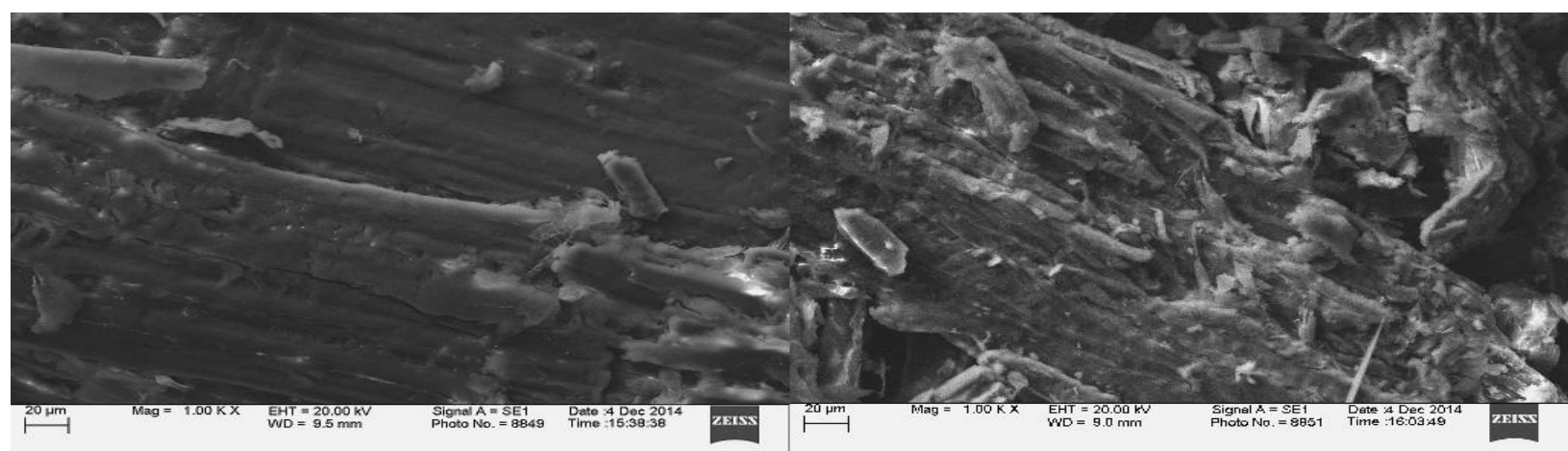

a.

b.

Figure 7 SEM image of raw pine (a) and torrefied pine (b)

380 As seen in Figure 8, a higher degradation of the char particles is observed with the increase in

381 temperature. It shows that even at higher temperatures such as 935 or $1000^{\circ} \mathrm{C}$ cell walls are not 
completely damaged. This implies that either the actual temperature of the particles was much

383 lower than what the gasification temperature was or some the particles were entrained during the

384 gasification without decomposing totally during gasification. In addition, as the gasification

385 temperature increase, more voids are visible and it could be due to the ejection of volatile matter

386 from cell walls.

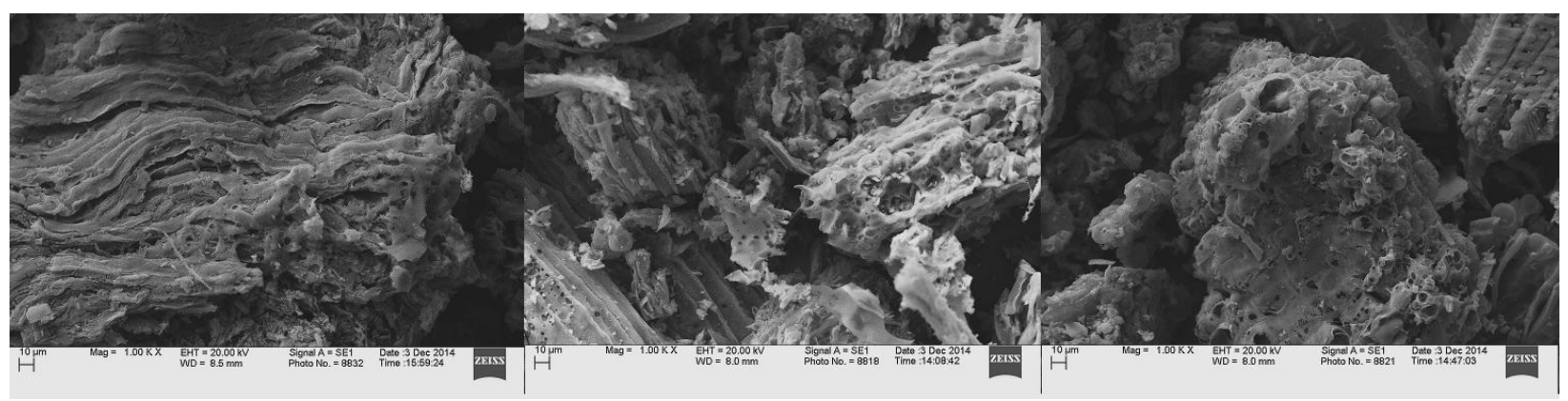

a.

b.

c.

389 Figure $8 \mathrm{SEM}$ images of char obtained for experimental runs performed at $790^{\circ} \mathrm{C}(\mathrm{a}), 935^{\circ} \mathrm{C}$ (b) and $1000^{\circ} \mathrm{C}$ (c)

391 Figure 9 shows the microscopic structure of biomass of the char particles obtained through 392 gasification at ER $0.20,0.25$ and 0.30 . With higher oxygen supply, the disintegration of the char 393 structure was more prominent, resulting in larger voids, which could be result of increase in the 394 char reactivity or higher temperature of the particles with increase in ER.

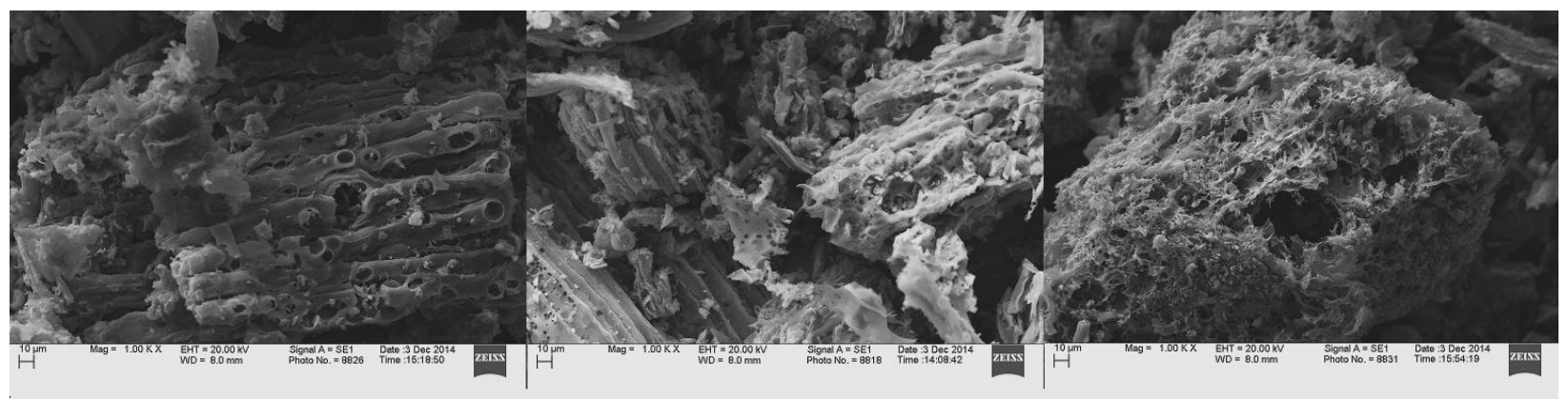

b.

c.

397 Figure 9 SEM images of char obtained for experimental runs performed at ER: 0.20 (a), 0.25(b) 398 and 0.30 (c) 


\section{Conclusions and remarks}

400 This experimental study was performed to understand performance of torrefied pine as a 401 gasification fuel in a bubbling fluidized bed gasifier and compare its performance with raw pine.

402 A parametric study was performed to comprehend the effects of temperature and equivalence 403 ratio on gasification of torrefied pine. Most importantly along with syngas composition, syngas 404 contaminants $\left(\mathrm{SO}_{2}, \mathrm{COS}, \mathrm{HF}, \mathrm{HCl}, \mathrm{NH}_{3}, \mathrm{HCN}\right.$ and tar) were also studied. Nitrogen contaminants $405 \mathrm{NH}_{3}$ and $\mathrm{HCN}$ were obtained in the range of 450 to $650 \mathrm{ppm}$ and 90 to $180 \mathrm{ppm}$, respectively. $406 \mathrm{H}_{2} \mathrm{~S}$ was around $70 \mathrm{ppm}$, while $\mathrm{SO}_{2}$ and $\mathrm{COS}$ were in reported between 80 to $100 \mathrm{ppm}$ and 5 to $40712 \mathrm{ppm}$ respectively. $\mathrm{HCl}$ and $\mathrm{HF}$ were less than $2 \mathrm{ppm}$. The tar yield obtained was between 1.5 408 to $3.8 \mathrm{~g} / \mathrm{dry} \mathrm{kg}$ of biomass. The temperature and equivalence ratio did not have any significant 409 effect on contaminant yield. Though temperature influenced the primary syngas composition to 410 certain extent, equivalence ratio range in this study did not affect the syngas composition except 411 for $\mathrm{CO}_{2}$.

412 From this study, it can be concluded that the higher carbon content in the torrefied pine did not 413 translate to higher carbon in syngas, rather resulted in higher char formation, while producing 414 lower liquid yield than raw pine when compared under similar gasification conditions 415 (temperature and ER). One of the major advantages of torrefied pine gasification was lower tar 416 production (3.8 $\mathrm{g} / \mathrm{kg}$ of biomass) during gasification as compared to raw pine ( $8 \mathrm{~g} / \mathrm{kg}$ of 417 biomass). Also, torefied pine produced lower amount of $\mathrm{NH}_{3}(600 \mathrm{ppm})$ than raw pine (1100 $418 \mathrm{ppm})$. Torrefaction of pine in in fact resulted in lower heating value as compared to raw pine. . 


\section{5. Acknowledgements:}

420 Authors would like to thank the United States Department of Agriculture-National Institute of 421 Food and Agriculture (USDA-NIFA) for providing funding for this research through the 422 Integrated Biomass Supply Systems (IBSS) project (2011-68005-30410). Also, authors would 423 like to thank Lucas Santos, a student participated through Brazilian Mobility in Science Program, 424 for helping with experimental work. 


\section{References:}

$427 \quad$ 1. $\quad$ EIA, U.S., Monthly Energy Review July 2015.

428 2. Demirbaş, A., Sustainable cofiring of biomass with coal. Energy Conversion and 429 Management, 2003. 44(9): p. 1465-1479.

430 3. Ericsson, K., Co-firing-A strategy for bioenergy in Poland? Energy, 2007. 32(10): p. 1838-1847.

4. McIlveen-Wright, D.R., et al., A technical and environmental analysis of co-combustion of coal and biomass in fluidised bed technologies. Fuel, 2007. 86(14): p. 2032-2042.

5. Baxter, L., Biomass-coal co-combustion: opportunity for affordable renewable energy. Fuel, 2005. 84(10): p. 1295-1302.

6. McKendry, P., Energy production from biomass (part 1): overview of biomass. Bioresource technology, 2002. 83(1): p. 37-46.

7. Zhang, L., C. Xu, and P. Champagne, Overview of recent advances in thermo-chemical conversion of biomass. Energy Conversion and Management, 2010. 51(5): p. 969-982.

8. Bergman, P., et al., Torrefaction for biomass co-firing in existing coal-fired power stations. Energy Centre of Netherlands, Report No. ECN-C-05-013, 2005.

9. Phanphanich, M. and S. Mani, Impact of torrefaction on the grindability and fuel characteristics of forest biomass. Bioresource technology, 2011. 102(2): p. 1246-1253.

10. Bridgeman, T., et al., An investigation of the grindability of two torrefied energy crops. Fuel, 2010. 89(12): p. 3911-3918.

11. Kokko, L., et al., Comparing the energy required for fine grinding torrefied and fast heat treated pine. Biomass and Bioenergy, 2012. 42: p. 219-223.

12. Repellin, V., et al., Energy requirement for fine grinding of torrefied wood. Biomass and Bioenergy, 2010. 34(7): p. 923-930.

13. Prins, M.J., K.J. Ptasinski, and F.J. Janssen, More efficient biomass gasification via torrefaction. Energy, 2006. 31(15): p. 3458-3470.

14. Dudyński, M., et al., Biomass gasification: Influence of torrefaction on syngas production and tar formation. Fuel Processing Technology, 2015. 131: p. 203-212.

15. Kuo, P.-C., W. Wu, and W.-H. Chen, Gasification performances of raw and torrefied biomass in a downdraft fixed bed gasifier using thermodynamic analysis. Fuel, 2014. 117, Part B(0): p. 1231-1241.

16. Sarkar, M., et al., Gasification performance of switchgrass pretreated with torrefaction and densification. Applied Energy, 2014. 127: p. 194-201.

17. Shreshtha, R., Experimental analysis and modeling of biomass gasification using a downdraft. 2014.

18. Strandberg, M., From torrefaction to gasification: Pilot scale studies for upgrading of biomass, in Department of Applied Physics and Electronics. 2015, Umeå University.

19. Xue, G., et al., Impact of torrefaction on properties of Miscanthus $\times$ giganteus relevant to gasification. Fuel, 2014. 121: p. 189-197.

20. Sluiter, A., et al., Laboratory Analytical Procedure: determination of structural carbohydrates and lignin in biomass. 2008, National Renewable Energy Laboratory

21. Abdoulmoumine, N., A. Kulkarni, and S. Adhikari, Effects of Temperature and Equivalence Ratio on Pine Syngas Primary Gases and Contaminants in a Bench-Scale Fluidized Bed Gasifier. Industrial \& Engineering Chemistry Research, 2014. 53(14): p. 5767-5777. 
22. Tapasvi, D., et al., Torrefaction of Norwegian birch and spruce: an experimental study using macro-TGA. Energy \& Fuels, 2012. 26(8): p. 5232-5240.

23. Doassans-Carrère, N., S. Muller, and M. Mitzkat, REVE - a new industrial technology for biomass torrefaction: pilot studies. Fuel Processing Technology, 2014. 126(0): p. $155-162$.

24. Nepune, S., Effect of torrefaction on biomass structure and product distribution from fast pyrolysis. 2014.

25. Carpenter, D.L., et al., Pilot-scale gasification of corn stover, switchgrass, wheat straw, and wood: 1. Parametric study and comparison with literature. Industrial \& Engineering Chemistry Research, 2010. 49(4): p. 1859-1871.

26. Narvaez, I., et al., Biomass gasification with air in an atmospheric bubbling fluidized bed. Effect of six operational variables on the quality of the produced raw gas. Industrial \& Engineering Chemistry Research, 1996. 35(7): p. 2110-2120.

27. Campoy, M., et al., Air- Steam Gasification of Biomass in a Fluidized Bed under Simulated Autothermal and Adiabatic Conditions. Industrial \& Engineering Chemistry Research, 2008. 47(16): p. 5957-5965.

28. Fisher, E., et al., Combustion and gasification characteristics of chars from raw and torrefied biomass. Bioresource technology, 2012. 119: p. 157-165.

29. Van der Drift, A., J. Van Doorn, and J. Vermeulen, Ten residual biomass fuels for circulating fluidized-bed gasification. Biomass and Bioenergy, 2001. 20(1): p. 45-56.

30. Lv, P., et al., An experimental study on biomass air-steam gasification in a fluidized bed. Bioresource technology, 2004. 95(1): p. 95-101.

31. Aljbour, S.H. and K. Kawamoto, Bench-scale gasification of cedar wood-Part II: effect of operational conditions on contaminant release. Chemosphere, 2013. 90(4): p. 15011507.

32. Xie, J.-j., et al., Emissions of $\mathrm{SO} 2, \mathrm{NO}$ and $\mathrm{N} 2 \mathrm{O}$ in a circulating fluidized bed combustor during co-firing coal and biomass. Journal of Environmental Sciences, 2007. 19(1): p. 109-116.

33. Gai, C., Y. Dong, and T. Zhang, Distribution of sulfur species in gaseous and condensed phase during downdraft gasification of corn straw. Energy, 2014. 64: p. 248-258.

34. Duong, D.N., et al. Chlorine issues with biomass cofiring in pulverized coal boilers: sources, reactions, and consequences-a literature review. in 34 th International Technical Conference on Coal Utilization and Fuel Systems, Clearwater FL. 2009.

35. Krishnan, G.N., R. Gupta, and R. Ayala. Development of disposable sorbents for chloride removal from high-temperature coal-derived gases. in Proceeding of the Advanced CoalFired Power Systems. 1999.

36. Milne, T.A., N. Abatzoglou, and R.J. Evans, Biomass gasifier" tars": their nature, formation, and conversion. Vol. 570. 1998: National Renewable Energy Laboratory Golden, CO.

37. Basu, P., Biomass gasification, pyrolysis and torrefaction: practical design and theory. 2013: Academic Press.

38. Devi, L., K.J. Ptasinski, and F.J.J.G. Janssen, A review of the primary measures for tar elimination in biomass gasification processes. Biomass and Bioenergy, 2003. 24(2): p. 125-140.

39. Chen, W.-H., et al., An evaluation on improvement of pulverized biomass property for solid fuel through torrefaction. Applied Energy, 2011. 88(11): p. 3636-3644. 
517 40. Phanphanich, M., Pelleting characteristics of torrefied forest biomass. 2010, University 518 of Georgia Athens, GA. 